\title{
Owen Fiss on Paradise Lost: The Judicial Bureaucracy in the Administrative State
}

\author{
Gilbert S. Merritt†
}

My view on Owen Fiss's paper on the rise of judicial bureaucracy in the administrative state is the traditional perspective of a federal judge. At least two other perspectives are possible. Professor Mashaw believes that in controlling the administrative state, federal courts, when not "impertinent," are "irrelevant." Professor Mashaw's position is interesting, but it is not one that I can take seriously as an Article III judge. The stereotypical judicial bureaucrat, in contrast, believes that he should be a "managerial judge." Professor Fiss fears that this latter viewpoint may come to dominate judicial thinking. I will start with the viewpoint of this consummate judicial bureaucrat, explain my own view, and end with a suggested method for handling section 1983 and similar cases against state and local officials, which are the major source of judicial bureaucratization.

I.

In reply to Owen Fiss, my interlocutor, a phantom colleague on the federal district court bench, dissents as follows:

My job on the district court is operational, not conceptual. I have seven hundred cases on my trial docket. One hundred are complex cases with extensive discovery, in which protective and many other kinds of orders must be entered and lengthy pretrial conferences conducted. Without management the trials will take forever; lawyers at $\$ 200$ an hour will try to depose everyone in sight and rifle through thousands of document files. In several other cases, I am supervising, after trial and judgment, the management of a school, a prison, a hospital, and several corporations. In ten others, a party is seeking immediate injunctive relief. Fifty are criminal cases awaiting arraignment, trial, or sentencing with bail and discovery motions, suppression hearings, and probation office work to be overseen. I have

† Judge, United States Court of Appeals for the Sixth Circuit.

1. Mashaw, "Rights" in the Federal Administrative State, 92 YALE L.J. 1129 (1983).

2. See Resnick, Managerial Judges, 96 HARV. L. REV. 374 (1982) (discussion of managerial tasks of federal district courts). 
four hundred others to keep moving-diversity, social security, civil rights, habeas corpus, bankruptcy, patent, admiralty, and so on.

Professor Fiss may think of me as a judge-a blindfolded virgin with sword and scales-but I am a manager at a litigation assembly plant with a computer, printer, and Xerox machine. I supervise data, docket clerks, law clerks, court reporters, lawyers, paralegals, probation officers, magistrates, and masters. Legal administration is my field. Better for me a degree in business, public administration, or computer science than law.

The icon of the blindfolded virgin fell off my desk and broke some years ago. To take its place, my law clerks gave me a print of an artist's conception of Paradise Lost. It depicts "Chaos Umpire," who, in Milton's words, "sits, And by decision more imbroils the fray, By which he Reigns." Since the rest of Milton's verse says that next to Chaos Umpire stands "high Arbiter Chance [who] governs all,"3 I have placed next to Paradise Lost two photographs showing the judges of my Court of Appeals and the Supreme Court.

Professor Fiss and his friends sometimes refer to a legal opinion as an "authoritative text" in order to connect it to other writings of the same genus-papal bulls, constitutions, treaties, statutes, committee reports, administrative rulings, and Biblical commands." In their view, "authoritative texts" are to be distinguished from poems, paintings, musical scores, histories, and magazine articles.

But Professor Fiss does not complain that papal bulls are written by a Vatican bureaucrat rather than the Pope. He does not despair that not a word of most statutes was written by a Congressman or Senator, nor that the Commissioners of the ICG, the FTC, the SEC, and the NLRB may not write or edit one word of opinions or rulings published in their names. He does not even care that he does not know who wrote the Books of Joshua, Judges, Isaiah, or Malachi. He knows that God did not actually write the Ten Commandments on Sinai, but he does not care that he does not know who wrote the Twentieth Chapter of Exodus, where the Commandments are given as "authoritative texts."

But woe unto judges who rely too much on nameless law clerks, staff attorneys, magistrates, and special masters. Fiss insists that judges must either write their own opinions, or fly-speck and carefully edit, sentence by sentence, what goes out in their name. He insists that the judges must understand the cases themselves and that their opinions must be their own work. In creating their authoritative texts, judges must act like poets, composers, and preachers who write their own poems, songs, and sermons. Judges are engaged in an aesthetic act and it would be a profanation of their office to delegate the creative act to another.

3. J. MflTON, PARADISE LOST, Bk. II, lines 907-09 (London 1667).

4. See Vining, Justice, Bureaucracy, and Legal Method, 80 MicH. L. REv. 248 (1981). 


\section{Comment on Fiss}

Professor Fiss does not understand that I am a manager of events, appointed to get a job done, and that what is important is not so much the process and the creative act but the result, the practical consequences, the effect on society. Like senators, university administrators, newspaper publishers, and major executives, I must concentrate on the big picture and delegate responsibility to others to carry out my orders. Nobody reads district court opinions these days except the parties. Gone are the days of the poets and philosophers of the law like Marshall, Shaw, Holmes, Hand, Cardozo, and Traynor.

Although my phantom judge is now little more than a speck on the horizon, we should share Owen Fiss's concern that he may be the wave of the future ${ }^{6}$ and that the old icon of disinterested justice may be cracking. ${ }^{6}$ A few district judges talk this way from time to time. To the consternation of many, Judge Alcee Hastings recently admitted at his trial for bribery that he had not read the Court of Appeals' opinion on which his decision had been based, and observed that judges often rule on the basis of clerks' research. ${ }^{7}$ We hear stories of appellate judges who simply order the law clerk to produce a result and do not participate in the process or shape the reasoning of the opinion.

These judges are certainly not the norm. Most federal judges do not want to become managers. No limousines or Lear jets come with the job. They complain about, and delegate to others, the managerial tasks they have to perform.

Most federal judges understand that their special place, their power in our society, is not personal. Our authority comes from the common law

5. I doubt that some of the signs Professor Fiss points to in the federal appellate courts are really symptoms of bureaucratic attitudes. The advent of the staff attorney, the summary affirmance, and oral dispositions from the bench seem justified, if used within reasonable limits. These interventions are designed to deal with a rising volume of meritless cases and motions. I do not favor imposing the English practice of deterring meritless cases, motions, and arguments by assessing attorneys' fees against the loser, but we must have some way to deal with the problem by screening out and quickly deciding the easy cases so that we will have time to study carefully the difficult ones.

6. A number of other judges have recently expressed a concern about this problem. See, e.g., Edwards, $A$ Judge's View on Justice, Bureaucracy, and Legal Method, 80 MICH. L. REV. 259 (1981) (Circuit Judge, United States Court of Appeals for the District of Columbia); Godbold, Improvements in Appellate Procedure: Better Use of Available Facilities, 66 A.B.A. J. 863 (1980) (Circuit Judge, United States Court of Appeals for the Fifth Circuit); Higginbotham, Bureaucracy-The Carcinoma of the Federal Judiciary, 31 ALA. L. REV. 261 (1980) (Circuit Judge, United States Court of Appeals for the Fifth Circuit; at time of Symposium, United States District Court Judge, Northern District of Texas); Mikva, More Judgeships-But Not All at Once, 39 WASH. \& LEE L. REV. 23 (1982) (Circuit Judge, United States Court of Appeals for the District of Columbia); Powell, Are The Federal Courts Becoming Bureaucracies?, 68 A.B.A. J. 1370 (1982) (Associate Justice, United States Supreme Court); Rubin, Bureaucratization of the Federal Courts: The Tension Between Justice and Efficiency, 55 NoTRE DAME LAW. 648 (1980) (Circuit Judge, United States Court of Appeals for the Fifth Circuit).

7. N.Y. Times, Feb. 1, 1983, at A15, col. 1. 
tradition of disinterested judgment-the rational development and application of legal principles that resolve disputes through the traditional methods of precedent, analogy, logic, and social utility described by Cardozo here at Yale sixty years ago. ${ }^{8}$ Over time, managerial judges and bureaucratic justice could become a pressing problem, or even a fatal illness, for the judicial branch. In our attempt to prevent this illness, Owen Fiss has provided a helpful theoretical framework.

\section{II.}

From my perspective, the threat of judicial bureaucracy and malfunction arises from certain aspects of the responsibility of federal courts to restrain and remedy official abuse in the administrative state. Some statistics from the Sixth Circuit set the stage for my discussion.

Sixty years ago, the Sixth Circuit had three circuit judges and decided 103 appeals. Thirty percent of those were criminal and tax appeals. The other seventy percent were private civil cases applying law between private individuals and corporations in diversity, patent, admiralty, and similar cases. At that time we had no so-called public interest cases, and no section 1983 or administrative law cases or constitutional and statutory claims asking our court to review the official actions of other government officials and agents-federal, state, or local. ${ }^{9}$

During 1982, the eleven active and five senior judges of our court, with the help of many district judges sitting with us by designation, decided 2000 appeals on the merits. Almost half were constitutional, administrative, and statutory claims in which the court was called upon to review the actions of other government officials and institutions. A great many were section 1983 or constitutional tort claims in which we were asked to review and invalidate some action of a state or local official.More than twenty-five percent were meritless cases decided without oral argument. ${ }^{10}$ Twenty-five percent of the cases on the oral argument calendar raised no substantial question and either were decided or could have been decided from the bench.

We could discuss at length the reasons for an increase in officialconduct cases from none sixty years ago to half of our current docket. The short answer is that, although the population has only slightly more than

8. See B. Cardozo, The Nature of the JUdiclal Process (1921) (series of lectures delivered at Yale).

9. For Sixth Circuit cases for the year 1921, see volumes 270 through 280 of the Federal Reporter.

10. These statistics are based on unpublished reports prepared for our court by John Hehman, the Clerk of the Court. 
doubled, ${ }^{11}$ the expenditure of all governments in the United States since the years shortly after World War I has increased more than one hundred times. ${ }^{12}$ Civilian government employment in that period has increased dramatically, to more than fifteen million people. ${ }^{13}$ The proliferation of federal legislation and regulation, with its attendant increase in federal employment, is well-known. ${ }^{14}$ The much greater proliferation of state and local legislation, and with it state employment, is less often discussed. ${ }^{15}$

The most pressing problem we confront as judges is the legal control of government officials, particularly at the state and local level. As a result of the historical development vesting jurisdiction to correct official abuse in the civil courts, ${ }^{16}$ the courts, and now particularly the federal courts, are major institutions for protection of the citizen against abuse by officials at all levels of government.

Federal judicial authority to correct such abuse is broad and derives from many sources. The forms of action allowing review of official conduct are many and varied-for example, direct actions in tort under the Constitution; actions in tort and contract under sections 1983 and 1981 for constitutional, statutory, and common law deprivations; review under the Administrative Procedure Act and under many specialized laws governing enviromental protection and occupational and consumer safety; and fed-

11. While the population of the United States was 106.5 million in 1920, it was 232 million in 1982. BUREAU OF THE CENSUS, U.S. DEP'T. OF COMMERCE, STATISTICAL ABSTRACT OF THE UNITED STATES, 1984, at 6 [hereinafter cited as STATISTICAL ABSTRACT OF THE UNITED STATES].

12. In 1922, governments at all levels spent a total of $\$ 9.297$ billion. BUREAU OF THE CENSUS, U.S. DEPT. OF COMMERCE, 2 HISTORIGAL STATISTICS OF THE UNITED STATES 1120 [hereinafter cited as HISTORICAL STATISTICS OF THE UNITED STATES]. In 1980, governments at all levels spent $\$ 958.7$ billion. STATTSTICAL ABSTRACT OF THE UNITED STATES, supra note 11, at 273.

13. STATISTICAL ABSTRACT OF THE UNITED STATES, supra note 11, at 303.

14. For example, in 1922 the total staff of the federal judicial branch was 1,880 . HISTORICAL STATISTICS OF THE UNITED STATES, supra note 12, at 1102 . By 1981, that staff had increased to 15,000. STATISTICAL ABSTRACT OF THE UNITED STATES, supra note 11, at 336. In the period from 1950 to 1981 , however, federal civilian employment increased only from 2.117 million to 2.865 million. STATISTICAL ABSTRACT OF THE UNITED STATES, supra note 11, at 303.

15. State and local government employment increased from 4.285 million in 1950 to 13.103 million in 1981. STATISTICAL ABSTRACT OF THE UNITED STATES, supra note 11, at 303.

16. In earlier centuries the evolving areas of law required the judicial branch to develop and apply principles governing land ownership and transfer, and then to develop principles for controlling violence through the law of crime and tort. Later still, with the rise of trade and the industrial revolution, courts had to develop principles of contract and restitution. The control of the administrative state was not a problem that the judicial branch had to spend much time pondering.

This situation began to change, however, and the common law courts eventually "won a victory which, on balance, we may regard as fortunate" against the administrative agencies of the Tudor period, the Star Chamber and the High Commission. T. PLUNKETT, A CONCISE HISTORY OF THE COMMON LAW 197 (5th ed. 1956). Similarly, over several centuries the common law courts restricted the activities of the network of ecclesiastical courts covering England. The common law courts rejected the civil law concept of the droit administratif and won the right to protect the public from the abuse of official power. See id. at 191-98 for discussion of the historical development of the common law courts in these respects. 
eral criminal laws punishing various forms of bribery and official corruption.

The great new challenge for the federal courts is to develop constitutional, statutory, and administrative law doctrines to govern the exercise of official power by government employees and officials. The problem is to work out a stable system of judicial intervention which prevents the abuse of power by officials. We have not done that yet.

More than just liberal reformers and "judicial activists" seek to enlarge the federal judicial power to review the conduct of public officials, administrators, and legislators. Conservative reformers often adopt the same course. Congressional enactment of a host of federal criminal laws designed to attack official corruption at the state and local level-for example, the Travel Act, ${ }^{17}$ the Hobbs Act, ${ }^{13}$ and $\mathrm{RICO}^{19}$ - were supported in Congress by conservatives. ${ }^{20}$

The general causes of these proposals and the reasons that we have more cases and more complex structural and public law cases are those identified by Owen Fiss and Abe Chayes: ${ }^{21}$ the growth in the size and complexity of American society, the need to restrain official abuse and negligence, and a tendency toward centralization, unification, and nationalization of the legal system. In a modern, highly organized society, official acts and decisions intimately affect the well-being and opportunities of the citizenry, particularly those who are poor. We must have means of ensuring that administrative action which interferes with liberty and property does not exceed the bounds set by the Constitution and by the legislative branch.

17. 18 U.S.C. $\$ 1952$ (1982).

18. 18 U.S.C. § 1951 (1982).

19. 18 U.S.C. $\S \S 1961-1968$ (1982).

20. Another example of conservative support for proposals that would transfer new power to the federal judiciary involves their support for the balanced budget amendment to the Constitution, which the President proposed and is stiil pushing. S.J. Res. 58, 97th Cong., lst Sess. (1981); Balancing the Budget: Hearings Before the Senate Subcommittee on the Constitution of the Committee on the Judiciary to consider S.J. Res. 58, to propose a constitutional amendment to require a balanced Federal budget and to limit Federal taxing and spending, 97th Cong., 1st Sess. (1981); Constitutional Amendments to Balance the Federal Budget: Hearings Before the Subcommittee on Monopolies and Commercial Law of the House Committee on the Judiciary to consider proposals to amend the Constitution to require a balanced Federal budget or to limit Federal spending, 96th Cong. (1979-80). Under such amendments, federal courts apparently would tell Congress and the President that taxes must be raised and defense spending cut whenever the budget is out of balance. I say this because the federal judicial system would, I assume, take seriously its responsibility to enforce this constitutional provision.

21. In his seminal articles on public law litigation, Professor Chayes elaborates the point that the "public law trend does not simply reflect the political or ideological coloration" of liberal judges but is rooted in "changes in the larger social, political, and cultural environment." Chayes, Foreword: Public Law Litigation and the Burger Court, 96 HARV. L. REV. 4, 8 (1982); see also Chayes, The Role of the Judge in Public Law Litigation, 89 HARV. L. REV. 1281 (1976); Fiss, The Bureaucratization of the Judiciary, 92 YALE L.J. 1442. (1983). 
III.

The particular problem I want to address arises in the context of section 1983 and other similar cases against state and local officials. Specifically, at what point should the federal judicial branch intervene in the state and local administrative process to look at what has happened and see if there is a federal right to be enforced? Or, as lawyers and judges would put it, when should the federal courts require the exhaustion of state and local administrative and judicial remedies before hearing the merits of a claim? ${ }^{22}$

The two most recent Supreme Court decisions on the subject, the Patsy case $^{23}$ and the Fair Assessment Association case, ${ }^{24}$ reflect the confusion and instability in the law. In Patsy, the Court, in an opinion by Justice Marshall, appears to lay down the broad no-exhaustion rule that federal plaintiffs can complain about the actions of state and local officials without exhausting any state remedies. ${ }^{25}$ In answer to Justice Powell's dissent arguing that the requirement that plaintiff exhaust available and adequate administrative remedies "is firmly established in virtually every area of the law" and is required by "common sense, as well as by comity and federalism,"26 Justice Marshall replies that only Congress, not the courts, has the institutional competence to come up with a solution, given the complexity of the policy considerations involved. ${ }^{27}$

In the Fair Assessment Association case, Justice Brennan, joined by Justice Marshall and two other members of the Patsy majority, writes in concurrence that the no-exhaustion rule should not operate in a range of cases, the scope of which is unclear. Justice Brennan says that the noexhaustion rule does not apply where congressional intent to the contrary is clear-a relatively simple exception. But his opinion also says that federal courts should require exhaustion of state remedies when such an intent can be "fairly understood" from congressional action or is "in accord with congressional policy."28

The question of when federal courts should intervene to control official action at the state and local level under section 1983 has thus not been resolved. My view is that many of the points made by Justice Powell in

22. See generally Developments in the Law-Section 1983 and Federalism, 90 HARV. L. REV. 1133, 1264-74 (1977) (discussing exhaustion requirement in judicial and administrative contexts); Comment, Exhaustion of State Administrative Remedies in Section 1983 Cases, 41 U. CHI. L. REV. 537 (1974) (re-evaluating exhaustion requirement in section 1983 cases).

23. Patsy v. Board of Regents, 457 U.S. 496 (1982).

24. Fair Assessment in Real Estate Ass'n. v. McNary, 454 U.S. 100 (1982).

25. 457 U.S. at 516.

26. Id. at 536 (Powell, J., dissenting).

27. Id. at 512-15.

28. 454 U.S. at 136 (Brennan, J., concurring). 
his dissenting opinion in Patsy are correct. There is no justification for intervention in every constitutional tort and section 1983 case-the major areas in which the explosion of federal cases during the last twenty years has occurred-before state or local remedies have been exhausted. In the normal section 1983 case claiming official abuse at the level of state and local government-involving prisoners, welfare recipients, licensing, payment of taxes, illegal arrest, employment, and so on - there are state administrative and judicial forums in which federal as well as state claims can be raised. Why should state administrative and judicial remedies not be exhausted before the section 1983 claim against the state or local official is reviewed and decided in federal court? A rule requiring exhaustion would reduce case loads, the volume of frivolous cases, and the need to decide so many cases that turn on issues of federal jurisdiction and procedure rather than on the merits.

It is puzzling to me why we should develop and enforce a fairly clear set of exhaustion requirements in state habeas corpus cases, when a person's freedom is at stake-a set of principles that require thorough exhaustion of state administrative and judicial remedies ${ }^{29}$-and yet not require exhaustion for rights of lesser importance. The state prisoner convicted of murder and sentenced to death must exhaust his state judicial remedies. The barber who complains that the action of the local barber board in delaying the licensing process violates a federal right, the state employee fired without a hearing, or the state Medicaid recipient denied benefits may come directly into federal court without exhausting state administrative or judicial remedies. I see no valid justification for this difference in the law.

An extension of the habeas corpus doctrine of exhaustion to cases seeking review of state and local official action under section 1983 would not change or withdraw basic jurisdiction from the federal courts. It would simply reduce the present confusion about when we should intervene and bring clarity to the record when we do. Many more cases would be decided before they reach a federal court. I suggest it as one method for dealing with the real problem the federal courts are facing--the dramatic rise in section 1983 and similar claims against state and local officials. ${ }^{30}$

29. See 28 U.S.C. $§ \S ~ 2241-2256$ (1982); see also Engle v. Isaac, 456 U.S. 107 (1982) (prisoner forfeits constitutional claim because of failure to comply with state criminal procedure); Rose v. Lundy, 455 U.S. 509 (1982) (district court must dismiss habeas petitions containing both unexhausted and exhausted claims).

30. The fundamental reason for the no-exhaustion doctrine in cases reviewing state and local official conduct is historical. Section 1983 was passed after the Civil War to protect blacks from official abuse in the South. The state courts were part of the problem and could not be trusted. Today state courts are competent to adjudicate such claims. In any case, this historical basis does not even exist in non-race cases, which constitute the vast majority of $\S 1983$ cases today.

The Supreme Court has recently observed that state courts are competent to adjudicate federal 
An exhaustion requirement similar to the habeas corpus requirement would not prevent the adjudication of the claim in federal court. It would simply make use of state and local administrative and judicial bodies in the first instance. Just as in habeas corpus cases, if the plaintiff demonstrates that these remedies are inadequate, they need not be pursued before bringing the federal lawsuit.

\section{Conclusion}

If bureaucracy comes to the federal courts, it will not be because we are unable to deal with diversity, admiralty, antitrust, securities, and traditional federal question and federal administrative agency cases. It will be because we are unable to find adequate time and methods to deal with the volume, magnitude, and complexity of cases asking us to make a record and then review the daily activities of millions of officials at the state and local level. Adoption of a rule requiring exhaustion would help us deal more effectively with this problem. It will not, as in Professor Gilmore's description of a judicial heaven, make law unnecessary so that "the lamb will lie down with the lion." Nor will it entirely eliminate the possibility of the ultimate bureaucratization of the judiciary, that final judicial purgatory in which "there will be nothing but law and due process will be meticulously observed."31 But it will help preserve for a few more years the reign of Justicia, the blindfolded virgin, and prevent her overthrow in Paradise Lost by Chaos Umpire, who "sits, And by decision more imbroils the fray By which he Reigns."

claims. Allen v. McCurry, 449 U.S. 90, 103-05 (1980). Elected state judges may, however, be unduly responsive on controversial issues to the views of a majority of their constituents. But that problem can be solved by modifying the present rule that the doctrines of res judicata and collateral estoppel bar federal court review of state court judgments in $\S 1983$ cases. See id. at 96-105 (stating present rule). If the same exhaustion of state judicial remedies rules is applied in $\S 1983$ cases as we now apply in habeas corpus, we should also apply the habeas rule that the doctrine of res judicata does not bar federal review of state court judgments. If exhaustion is required, res judicata should not be used to bar access to the federal courts on the federal claim.

31. G. GILMORE, THE AGES OF AMERICAN LAW 111 (1977). 